\title{
Political Science as Prospect for Achieving Sustainable Development Goals in Nigeria
}

\section{Dr. Gerald E. Ezirim}

Corresponding author, gerald.ezirim@unn.edu.ng

Kelechi Elijah Nnamani

kelechi.nnamani.pg68541@unn.edu.ng

Dr. Vincent Chidi Onah

vincent.onah@unn.edu.ng

\section{Dr. Humphrey Nwobodo Agbo}

humphrey.agbo@unn.edu.ng

\section{Dr. Chinedu Cyril Ike}

chinedu-ike@outlook.com

\author{
Doi:10.5901/mjss.2016.v7n5p319
}

\begin{abstract}
With the continued manifestation and intensification of poverty, child and maternal mortality, unemployment, HIVIAIDS and other economic problems in Nigeria after the expiration of the deadline set for the realization of the Millennium Development Goals, the preoccupation of the existing scholarships have been channeled in interrogating the fundamental impediments to the actualization of these goals. Factors such as lack of human capacity, inadequate and unreliable data system, lack of finance, poor coordination of the policy framework, and among others, were identified by scholars as the bane of the MDGs framework in Nigeria. As the global community moves into the post-MDG era, the study examined the role and relevance of Political Science in advancing the objectives enshrined in the Sustainable Development Goals in Nigeria. Employing the basic propositions emanating from the Marxist theory of the Post-Colonial State, the study, beyond the conventional positions of scholars, argued that the non-adherence to the dictates of politics was implicated in the failure of Millennium Development Goals in Nigeria. Also, the study utilized the secondary method of data collection largely drawn from official publication, journal articles and books while we analyzed the data using the content analysis. In the light of the foregoing, we suggested for more inclusion of political scientists in the formulation and implementation of policy frameworks relating to SDG initiatives, on one hand, and the application of basic principles of good governance which remains the core of Political Science, on another hand, in order to address the development challenges that confronting the Nigerian state.
\end{abstract}

Keywords: Political Science, MDG, SDG, Child and Maternal Mortality, Poverty.

\section{Introduction}

Nigeria, as presently constituted, is a conglomeration of varied ethnic groups which prior to the historic amalgamation of 1914, were bereft of common social, economic and political background. The unification project orchestrated by the British imperialists ushered in an entity known and addressed as Nigeria. Meanwhile, by an act of the British Parliament, Nigeria became an independent country within the Commonwealth on October 1, 1960. Dr. Nnamdi Azikiwe was installed as governor general of the federation and Balewa continued to serve as head of a democratically elected parliamentary system of government, not until 1963 when the Queen ceased being the Head of State. The Governor-General represented the British monarch as head of state and was appointed by the crown on the advice of the Nigerian prime minister in consultation with the regional premiers. The governor general, in turn, was responsible for appointing the prime minister and for choosing a candidate from among contending leaders when there was no parliamentary majority. Otherwise, the governor general's office was essentially ceremonial (Dawodu, 2007). 
Nigeria is a federal republic with 36 states, a Federal Capital Territory and 774 local government areas. Moreover, the country is modeled after the United State presidential system of government where the executive power is vested on the democratically elected president. The country's legislative body, the National Assembly is a bicameral House, divided into Senate (the Upper Chamber made up of 109 members) and the House of Representatives (the Lower Chamber with 360 members). Meanwhile, the country's judiciary has the Supreme Court at the apex and presided over by the Chief Justice of the Federation.

Also, the country is richly endowed with enormous resources such as iron ore, limestone, salt, tin, coal, bitumen, arable lands and crude oil which accounts for her major earnings in the international market. According to World Bank (2015), Nigeria is the $20^{\text {th }}$ largest economy in the world with net worth more than $\$ 500$ billion and $\$ 1$ trillion naira in terms of nominal GDP and purchasing power parity. It is equally seen as an emerging market and has been identified as the regional power in the African continent, having been listed as the 'Next Eleven' economies set to become among the biggest in the world (World Bank, 2015).

However, the decolonization of the Nigerian state in the 1960 which was touted as a watershed in the socio-politico cum economic development of the country appeared to be a fantasy. Sadly, the developmental crisis ravaging the postcolonial Nigerian state has defied all known diagnostic medications.

In 1999, Nigeria keyed into the Millennium Development Goals initiative which was a global collective action targeted towards resolving the development challenges in the country by the year 2015. As 2015 which was the targeted year has elapsed, a critical evaluation of the progress made has shown that Nigeria did not achieve the desired results as stated in the framework.

As a corollary of the above reflections, the study through the aid of documentary method of data collection together with the qualitative/descriptive analysis, examined the role of Political Science in achieving the Post-Millennium Development Goals in Nigeria.

\section{Materials and Methods}

\subsection{Problematization of the Study}

Evidently, the post-colonial Nigerian state is grappling with enormous development problems which can be perceived from a tripartite viewpoint namely; political, economic and social. Politically, the country is enmeshed in institutionalized corruption, non-emergence of genuine leadership, flagrant abuse of human rights, ineffective and inefficient institutional mechanism of the state and gross abuse of the fundamental principles of rule of law, political instability, election malpractices, among others (Obasanjo, 1999; Dike, 2010; Onuoha et al 2015). Economically, Nigeria is plagued with pervasive poverty and unemployment rate, rising debt profile, high inflation rate, low human development index, unfavourable trade relations, food crisis (Nnamani, 2015). Socially, the Nigerian state is struggling with civil strife, terrorism, ethnic based militias, kidnapping, debased educational system, armed robbery, youth restiveness, human trafficking, religious-motivated conflicts, high maternal and infant mortality, malnutrition, gender inequality, high scourge of HIVIAIDS and other deadly diseases, illiteracy (George \& Ukpong, 2013; Nnamani, 2015).

However, the continued manifestation of the aforementioned challenges that beset the post-colonial Nigerian state was directly responsible for the initiation, experimentation and implementation of various strategic frameworks and developmental plans by successive governments, whose ultimate aim is the amelioration of the observed problems. The first National Development Plan in Nigeria lasted from 1962-1968 where Tafawa Balewa Government placed greater emphasis on education, health and employment; promotion of balanced development; promotion of equity in income and promotion of macro-economic stability. The second National Development Plan of 1970-1974 was basically initiated to build united, strong and self-reliant nation; a great and dynamic economy; a just and egalitarian society; land of bright and full opportunities for all citizens; and free and democratic society while the third National Development Plan of 1975-1980 spearheaded by Murtala/Obasanjo administration was meant to achieve increase in per capita income; even distribution of income; reduction in the level of unemployment; increase in the supply of high level manpower; diversification of the economy; balanced development and indigenization of economic activities (Ejumodo, 2013). Also, the fourth, fifth and sixth were equally developed and implemented to advance the course of Nigeria's development. Nevertheless, assessments of the aforementioned plans have shown that Nigeria could not realize its full potential objectives.

On the other hand, Nigeria has prioritized agricultural oriented and rural development initiative such as Operation Feed the Nation, Green Revolution, Better Life Nigeria, Family Support Programme, DFFRI, among others, in a bid to address the seemingly developmental crisis that engulfed the country without much progress.

In 1999, the country keyed into the Millennium Development Goals initiative with a view to systematically 
addressing the prevalent development challenges that plagued the country ever since it achieved the status of selfgovernment. The Millennium Development Goals (MDGs) represents the eight international development goals, launched during the Millennium Summit of the United Nations in 2000 at New York. However, as the 2015 which was the deadline set for the achievement of the targets enshrined in the MDG initiative has elapsed, scholarly and empirical studies have shown that Nigeria has failed to record meaningful progress from the initiative. As a result, extant literature identified poor coordination, absence of comprehensive policy framework, undue political interference, ineffective targeting of the poor, unwieldy scope of programmes resulting in resources being thinly spread among too many projects, over-lapping of functions, absence of sustainability mechanisms in programme/projects, lack of involvement of beneficiaries in project design, implementation, monitoring and evaluation as the fundamental factors that impeded on the actualization of the Millennium Development Goals in Nigeria.

However, as the international community embarks on journey in search of solutions to the lingering development challenges in the developing countries under the instrumentality of Sustainable Development Goals (SDG), this study departing from the extant studies, attempts to underscore the relevance of political science in achieving developmentdriven goals in Nigeria.

\subsection{Theoretical Dimension of the Study}

The study is predicated on the analytical and explanatory framework of the Marxist theory of the Post-Colonial State as enunciated, developed and used by scholars like Alavi (1972), Saul (1974), Ake (1985), Ekekwe (1985) and Ibeanu (1998) to examine the nature and character of states in the periphery. The Marxist theory of the post-colonial state arose as counteract to the Western/Liberal paradigmatic explanation of the state, which argued that the state is an independent force and a neutral entity that cater for the welfare of its citizens. Rather, the Marxist persuasion agreed that the state is a product and expression of the irreconcilability of class contradictions and antagonisms. Accordingly, the state arose as a powerful force, standing above the society and saddled with the responsibility of mediating and moderating the class struggle in order to keep them within the bounds of law (Engels, 1884; Lenin, 1918). Overtime, the state has absconded from this assumed role and, rather, positioned itself as a committee for managing the common affairs of the bourgeoisie and dominant class while subjugating the working class (Marx \& Engels, 1848). Here, the state expressed its preference for the dominant class over the subjugated class by enacting, executing and adjudicating laws that sustains and intensifies the oppression, subjugation and exploitation of the latter.

However, the central feature of the theory of the post-colonial state is its contention that the post-colonial state is a creation of imperialism. As a result, it has always followed the developmental strategies cum trajectories, dictated by the interest of imperialist and its local cronies, as against the interest of the majority of the indigenous population. Contributing, Alavi (1973:146) noted that "the post-colonial states and its apparatus are instruments of primitive accumulation by the dominant class and their collaborators". In the same vein, Ekekwe (1986) argued that the post colonial states rest on the foundation of the colonial state, this, in turn, had incorporated some important elements of the pre-colonial rudimentary state structures. The main goal of the colonial state was to create conditions under which accumulation of capital by the foreign bourgeoisie in alliance with the ruling elite would take place through the exploitation of local human and other natural resources. It was on this basis that the post-colonial state emerged.

Given this context, the stakes and struggles for state power are very high and often assume 'a zero-sum game approach. The limited autonomy of the post-colonial state in Africa leads to an exclusive politics articulated in the struggle for power based on efficiency norms rather than legitimacy norms; the triumph of the vicious over the virtuous circle; centralization of power; imposition of domination and political control; alienation of leaders from their masses; and the deployment of extremism in the exercise of power are all hallmarks of the postcolonial state which in effect, the 'people tendentially retreat into primary groups which become the beneficiary of their residual loyalty and explore other 'extrajuridical' and 'non-state means', which often have very high conflict potential. In the process, society becomes deeply divided and the alienation is endemic, while distrust and anxiety among the contending groups are so pronounced that the state stumbles and totters on the brink of disaster, almost headed for disintegration in a cycle of political violence, recrimination and war (Ake 1982).

On his part, Ibeanu (1998) contended that the colonial state, due to the distinct colonial experience at the stage of extensive growth of capital in which they emerged, did not strive for legitimacy as the raison d'être for their constitution was principally for conquering and holding down the peoples of the colonies, seen not as equal commodity bearers in integrated national markets, but as occasional petty commodity producers (Ibeanu, 1998). Owing to this, there was no effort made to evolve, routinize and institutionalize principles for the non-arbitrary use of the colonial state by the colonial political class. And when in the post-colonial era this state passed into the hands of a pseudo capitalist class fervently 
seeking to become economically dominant, it becomes, for the controllers, a powerful instrument for acquiring private wealth, a monstrous instrument in the hands of individuals and pristine ensembles for pursuing private welfare to the exclusion of others (Ibeanu, 1998). Against this background, Ibeanu maintained that the abiding assault on governance in Nigeria should be located in the character of the Nigerian state as institution that have continued to undermine good governance are genealogically inscribed in it.

In the light of the foregoing elaborations, the theory is germane in explaining and understanding the persistent failures of all the strategic frameworks initiated to salvage the developmental challenges of Nigeria particularly, the Millennium Development Goals. As a post-colonial state, Nigeria has always exhibited the fundamental features of a typical post-colonial state such as: capitalist rent seeking, prebendalism and patrimonialism, which studies have implicated as undermining the country's capacity to discharge those fundamental obligations of modern state to her citizens (Jega, 2002 cited in Eme \& Okwueze, 2014). Moreover, the theory is critical to appreciating that Nigeria, being a post/neo-colonial state created the opportunity for the hegemonic faction of the ruling class in Nigeria to craft poverty alleviation programmes in such a way that it will help to perpetuate dominance and subjugation against the masses of the Nigerian society. Because, the leaders in the post-colonial states are preoccupied with primitive capital accumulation rather than the general welfare of the citizens, they enthrone mediocrity by employing cronies and relatives who have little or no knowledge, and entrust them with the mandate of initiating and implementing development programmes. This had led to the politicization and subsequent failures of development initiatives including the Millennium Development Goals.

\section{Results and Discussions}

\subsection{Understanding the Brief History of Millennium Development Goals Framework}

The intensification of underdevelopment and poverty in the international system, occasioned by the global depression of 1980s, was directly responsible for the adoption of World Bank and the International Monetary Fund's structural adjustment programme such as trade liberalization, privatization and other market-oriented policies by some states. However, by late 1980s, it became a well known fact, based on available studies that the neo-liberal economic framework and prescriptions of the World Bank/International Monetary Fund could not transport the third world countries into the realm of economic prosperity (Callaghy, 1986; Cornia et al, 1987; Cornia \& Hellinger, 1994; Carmody, 1998).

As countries began expressing disenchantment with the failure of the structural adjustment programs, the United Nation saw the need to initiate plans on how best to tackle the myriad of problems that confront the world, particularly the third world countries in the new millennium. This idea culminated into hosting and organizing of intense, historically unprecedented UN conference process, aimed at "building consensus" on development priorities for the $21^{\text {st }}$ century. These ranges from the 1994 Cairo conference on population, 1995 Beijing conference on women in particular,1995 Copenhagen World Summit on Social Development among others (Marguerite, 2010). Principally, the Copenhagen World Summit on Social Development can best, be described as historic landmark in the formation of the Millennium Development Goals framework. This is because; the 10 point declaration made and adopted at the conference latter, laid foundation for the Millennium Development Goals.

However, following the Millennium Summit held in 2000, the World Leaders under the aegis of $55^{\text {th }}$ General Assembly of the United Nations, unanimously adopted the Millennium Declaration in New York-- a declaration which ideologically builds on the conference process of the 1990s. The Declaration, signed by 147 heads of states, substantially draws from the UN Secretary General Millennium Report published in April 2000, We the Peoples: The Role of the United Nations in the 21st Century. Subsequently, in September 2001, the MDGs were approved by the 56th UN General Assembly.

The MDG initiative was borne out of the need to tackle and resolve the growing incidence of poverty and economic crisis that characterized the underdeveloped and developing countries of the world in the new millennium. The Millennium Development Goals originated from the Millennium Declaration agreed by the 147 heads of state and government which encompasses the roadmap to holistic and sustainable development in the developing countries of the world by the year 2015. In the Millennium Declaration, the World Leaders stressed that:

Every individual has dignity and freedom; and hence, the right to freedom, equality, and a basic standard of living that includes freedom from hunger and violence and encourages tolerance and solidarity (Deneulin \& Shahani, 2009).

In line with this, the world leaders made landmark commitment to tackle the fundamental challenges of the developing countries of the world by evolving and articulating eight objectives of Millennium Development Goals. The 
eight goals are as follow:

- Eradicating extreme poverty and hunger

- Achieving universal primary education

- Promoting gender equality and empowering women

- Reducing child mortality rates

- Improving maternal health

- Combating HIV/AIDs, malaria and other diseases

- Ensuring environmental sustainability

- Developing a global partnership for development

Table 1: Showing MDG Goals, Targets and Indicators

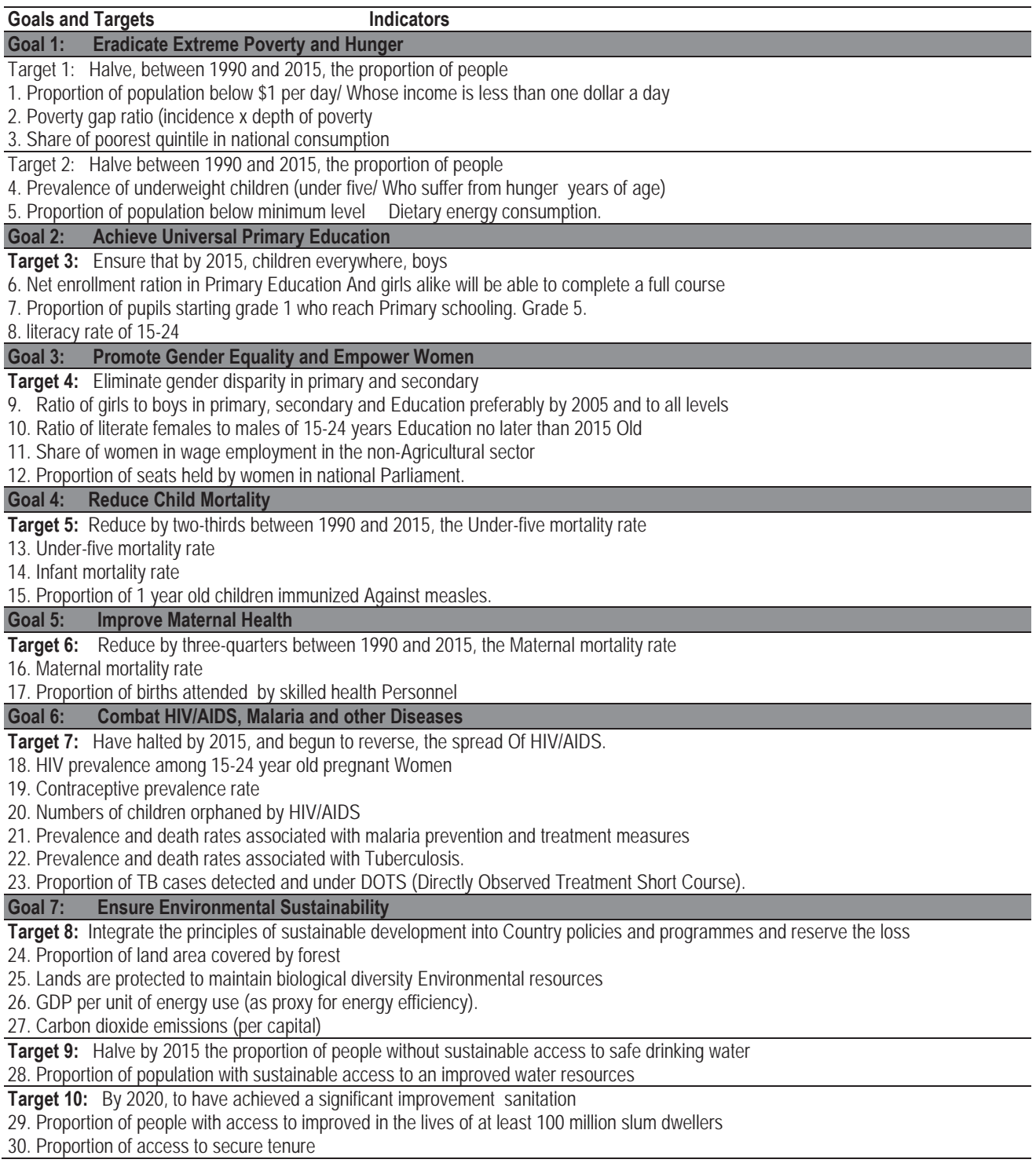




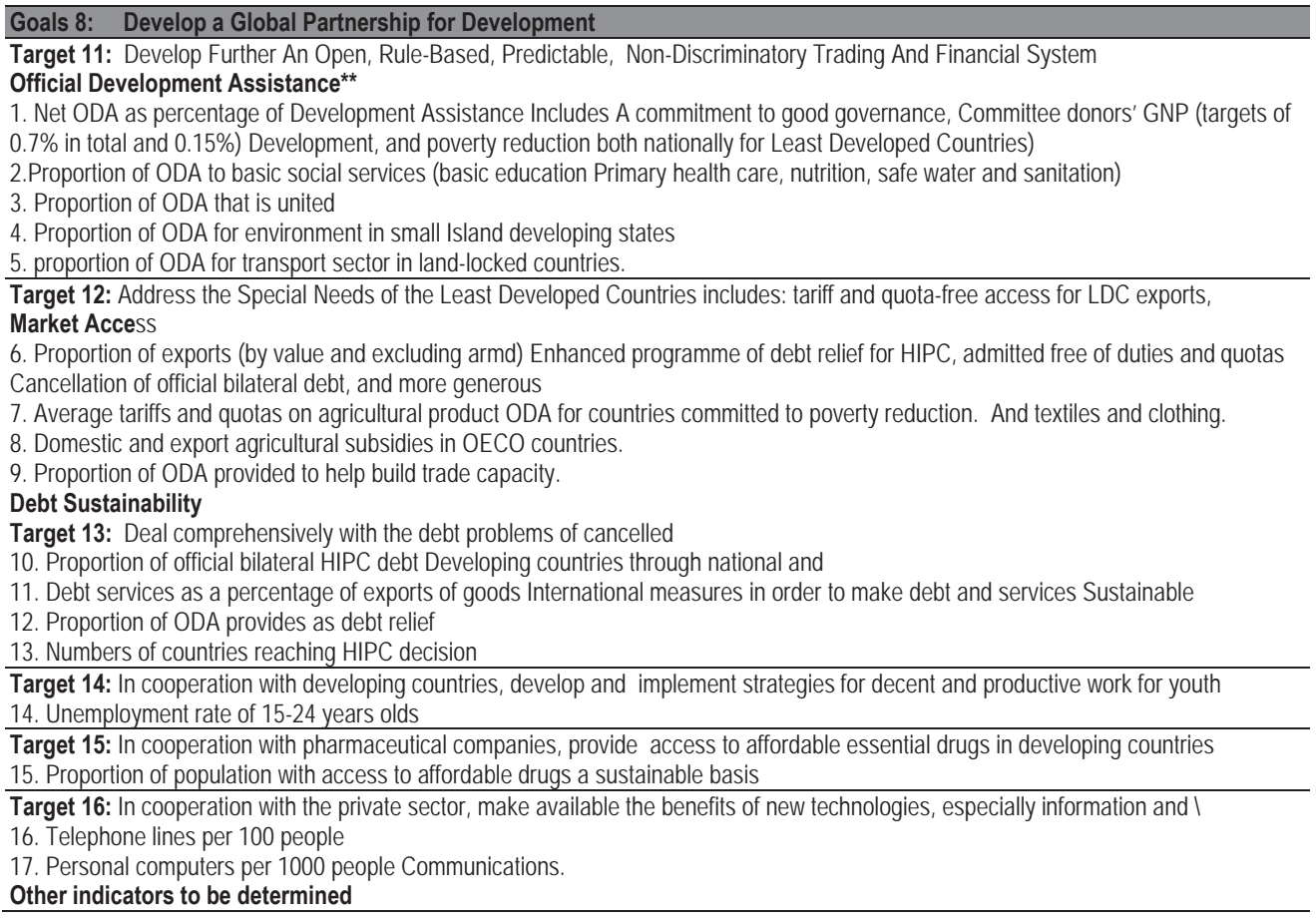

Source: MDG Debate to Action.

The initiative was meant to engage all the world leaders particularly the third world leaders to champion the course of development and also, provide a coherent strategic framework that will assist them in the developmental process.

\subsection{Assessment of Millennium Development Goals in Nigeria}

Since the discovery of oil in commercial quantity in Nigeria in 1956 and the oil boom of 1970s, oil has dominated the economy of the country. Oil accounts for more than 90 percent of the country's exports, 25 percent of the Gross Domestic Product (GDP), and 80 percent of government total revenues. As a result, the economy of the country has been substantially unstable, a consequence of the heavy dependence on oil revenue, and the volatility in prices. The oil boom of the 1970s led to the neglect of agriculture and other non-oil tax revenue sectors, expansion of the public sector, and deterioration in financial discipline and accountability. In turn, oil-dependence exposed Nigeria to the vagaries associated with oil price volatility which threw the country's public finance into disarray (Agbaeze, Udeh \& Onwuka, 2015:1).

The above excerpt aptly captured in the scholarly writing of Agbaeze, Udeh \& Onwuka (2015) can best, be described as the genesis of economic crisis in Nigeria. Prior to the discovery of oil in saleable quantity, agriculture was the mainstay of her economy. Similarly, peasant agricultural production for export offered her the needed impetus and incentive for overall economic growth (llugbuhi, 1968). Agriculture was seen as the sole employer of labour as it provided jobs for majority of Nigerian, particularly the rural populace. Furthermore, apart from its contribution to employment creation, poverty/hunger reduction and reduction in rural-urban drift, was also a source of major foreign exchange earnings of Nigeria (Olubunmi et al, 2015).

However, the advent of oil regime marked a new epoch in Nigeria's economic. As exploration began, hopes were high. Profit from oil sale was greatest during the "Golden Decade" of the 1970s, in which she became the wealthiest country in Africa. Between 1958 and 1974, oil production rose from 5000 to 2.3 million barrels per day and government revenue increasing from N200,000 to N3.7 billion (Niger Delta Politics, 2012; Odubiyi, 2013). Within two years, state profit increased by almost 50\% to an all-time high of N5.3 billion in 1976 (CBN, 2010). Nigeria bolstered profits when it joined OPEC in 1971, an organization which helped to construct the global petroleum scarcity, and thus the massive profitability 
of fossil fuels at the time. The economic prosperity was, however, short-lived.

Consequently, the drastic decline in the revenue of Nigeria occasioned by the oil glut in the international market exposed the country to economic recession which nearly, led to the collapse of its economy (Nnamani, 2015). Olowu, Laleye \& Ayeni (1982), observed that slow growth rate of national output, balance of payment crisis, mounting national output, balance of payment crisis, mounting national debt and debt servicing burden, deepening food shortage crisis, collapse of the manufacturing sector, mounting unemployment, galloping inflation and deteriorating standard of living are dramatic indicators of economic crisis. As a palliative and diagnostic measure aimed at cushioning the effects of the economic recession of 1980s, the government of Ibrahim Babangida keyed into the structural adjustment programs as propagated in the Washington Consensus and championed by the International Monetary Fund and World Bank. This development was largely responsible for the implementation of various market-oriented reforms like privatization, liberalization of trade, removal of subsidies and other macroeconomic adjustment policies, which, among other things, redefined the economic role of the state. Unfortunately, empirical and theoretical studies have demonstrated that the SAP strategies could not deliver on its numerous promises of resolving the economic challenges of Nigeria (OAU, 1980; Onimode, 1983; Osman, 1994; Okolie, 2015; Nnamani, 2015).

With the new millennium approaching, there was need to evolve new strategies and ideas in tackling the multifarious challenges that beset the Nigerian state. Owing to this, the Nigerian government embraced and aligned with the MDGs initiative as agreed by the gathering of the world leaders in New York in 2000. In this regard, the administration of President Olusegun Obasanjo, in its bid achieve the MDGs and halt the continued intensification of poverty, child and maternal mortality, debt burden, unemployment among others, initiated and developed a home-grown known as National Economic Empowerment and Development Strategy (NEEDS).

The National Economic Empowerment and Development Strategy is a coherent strategic framework and blueprint, embodying Nigeria's roadmap to sustainable and all-round development in the new millennium. The blueprint was developed in collaboration with the State Economic Empowerment and Development Strategy at the state level. Initially, the vision underlying the NEEDs agenda was to evolve an all-inclusive framework that would start at the national level down to the family level. In this light, attempts were made to design the Local Economic Empowerment and Development Strategy (LEEDs) at the local level, CEEDs at the community level and FEEDs at the family level. Nevertheless, it only succeeded at the national and state levels. Meanwhile, the NEEDs policy was anchored on four cardinal objectives which included wealth creation, employment generation, poverty reduction and value-reorientation. In line with the targets of the MDGs, NEEDs sought to fight against the many strands of poverty through job creation and empowerment of people to success.

However, as the 2015 which was earmarked as deadline for the achievement of the MDGs has elapsed, an examination of the critical and major indicators of development has shown the impracticability of the NEEDs policy objectives to advance its stated objectives. This can be demonstrated empirically in the following data as presented in the tables below:

Table 2: Human Development Index in Nigeria from 2001 to 2014

\begin{tabular}{|lc|}
\hline Year & Nigeria's Human Development Index \\
\hline 2001 & 0.463 \\
\hline 2002 & 0.466 \\
\hline 2003 & 0.453 \\
\hline 2004 & 0.448 \\
\hline 2005 & 0.470 \\
\hline 2006 & 0.506 \\
\hline 2007 & 0.511 \\
\hline 2008 & 0.483 \\
\hline 2009 & 0.419 \\
\hline 2010 & 0.423 \\
\hline 2011 & 0.467 \\
\hline 2012 & 0.471 \\
\hline 2013 & 0.500 \\
\hline 2014 & 0.504 \\
\hline
\end{tabular}

Source: Saheed \& Egwaikide, 2012, UNDP 2015. 
Table 3: Unemployment Rate in Nigeria 1999-2010

\begin{tabular}{|c|c|c|}
\hline \multicolumn{2}{|c|}{ Year } & Unemployment Rate in Nigeria (\%) \\
\hline 1. & 2000 & 13.1 \\
\hline 2. & 2001 & 13.6 \\
\hline 3. & 2002 & 12.6 \\
\hline 4. & 2003 & 14.8 \\
\hline 5. & 2004 & 13.4 \\
\hline 6. & 2005 & 11.9 \\
\hline 7. & 2006 & 12.3 \\
\hline 8. & 2007 & 12.7 \\
\hline 9. & 2008 & 14.9 \\
\hline 10. & 2009 & 19.7 \\
\hline 11. & 2010 & 21.1 \\
\hline 12. & 2011 & 23.9 \\
\hline 13. & 2012 & 27.4 \\
\hline 14. & 2013 & 24.7 \\
\hline 15. & 2014 & 26.5 \\
\hline
\end{tabular}

Source: IMF, 2014; NBS, 2012; CBN, 2015.

The data illustrated above indicate the Human Development Index (HDI) in Nigeria from 2001 to 2014. According to the UNDP (2012), the HDI is the composite statistic of life expectancy, education index and standard of living measured in Gross National Product Per Capita. In terms of grading, countries with figures ranging from 0.811 to 1.0 are deemed to have "Very High HDI", those within 0.711-0.810 are classified as "High HDI"; while countries with figures between 0.511 and 0.710 are known to have Medium HDI, those within 0.1-0510 are known as countries with Low HDI (Nnamani, 2015). However, the implication of these illustrations in the above table is that Nigeria is having Low HDI from 2000 to 2014. With this, we can conclude that Nigeria did not meet the MDGs 1 and 2. No doubt, the persistent decline in the HDI in Nigeria can be located in the burgeoning unemployment rate as demonstrated in the table 2 .

Table 4: Maternal Mortality Ratio and Under Five Mortality Rate in Nigeria from 2000 to 2015

\begin{tabular}{|lcc|}
\hline Year Maternal Mortality Ratio (Per $\mathbf{1 0 0 , 0 0 0 ~ l i v e ~ b i r t h s ) ~ U n d e r ~ F i v e ~ M o r t a l i t y ~ ( P e r ~} \mathbf{1 0 0 0}$ live births) \\
\hline 2000 & 1,770 & 187 \\
\hline 2001 & 1,140 & 181 \\
\hline 2002 & 1,090 & 176 \\
\hline 2003 & 1,040 & 170 \\
\hline 2004 & 986 & 164 \\
\hline 2005 & 946 & 158 \\
\hline 2006 & 890 & 152 \\
\hline 2007 & 884 & 146 \\
\hline 2008 & 829 & 141 \\
\hline 2009 & 883 & 136 \\
\hline 2010 & 867 & 130 \\
\hline 2011 & 824 & 126 \\
\hline 2012 & 819 & 121 \\
\hline 2013 & 821 & 117 \\
\hline 2014 & 820 & 113 \\
\hline 2015 & 814 & 109 \\
\hline
\end{tabular}

Source: World Bank, 2016.

Based on the foregoing data, it is obvious that Nigeria has failed in meeting up with the Millennium Development Goals 4 and 5 respectively. Although analyses of recent trends has shown that the country made significant progress in cutting 
down maternal and under-five mortality rates, the pace remained too slow to achieve the Millennium Development Goals (MDGs) of reducing maternal and child mortality by a third by 2015. According to the United Nations Children's Fund (UNICEF) record, "Every single day, Nigeria loses about 2,300 under-five-year-olds and 145 women of childbearing age. This makes the country the second largest contributor to the under-five and maternal mortality rate in the world". The deaths of new-born babies in Nigeria represent a quarter of the total number of deaths of children under-five. The majority of these occur within the first week of life, mainly due to complications during pregnancy and delivery reflecting the intimate link between new born survival and the quality of maternal care.

Table 5: HIVIAIDS and Tuberculosis Prevalence in Nigeria from 2001 to 2014

\begin{tabular}{|lccc|}
\hline Year & $\begin{array}{c}\text { No. of Persons Living with } \\
\text { HIVIAIDS in Nigeria }\end{array}$ & $\begin{array}{c}\text { Tuberculosis Case Detection } \\
\text { Rate }(\mathbf{\%})\end{array}$ & $\begin{array}{c}\text { Incidence of Tuberculosis } \\
(\mathbf{1 0 0}, \mathbf{0 0 0}) \text { People }\end{array}$ \\
\hline $\mathbf{2 0 0 1}$ & $2,700,000$ & 11 & 331 \\
\hline $\mathbf{2 0 0 2}$ & $2,700,000$ & 9 & 336 \\
\hline $\mathbf{2 0 0 3}$ & $3,500,000$ & 10 & 339 \\
\hline $\mathbf{2 0 0 4}$ & $3,600,000$ & 12 & 342 \\
\hline $\mathbf{2 0 0 5}$ & $3,600,000$ & 13 & 343 \\
\hline $\mathbf{2 0 0 6}$ & $3,600,000$ & 14 & 343 \\
\hline $\mathbf{2 0 0 7}$ & $3,600,000$ & 16 & 342 \\
\hline $\mathbf{2 0 0 8}$ & $3,600,000$ & 17 & 341 \\
\hline $\mathbf{2 0 0 9}$ & $2,600,000$ & 17 & 340 \\
\hline $\mathbf{2 0 1 0}$ & $2,600,000$ & 16 & 339 \\
\hline $\mathbf{2 0 1 1}$ & $3,300,000$ & 16 & 339 \\
\hline $\mathbf{2 0 1 2}$ & $3,300,000$ & 16 & 339 \\
\hline $\mathbf{2 0 1 3}$ & $3,300,000$ & 16 & 338 \\
\hline $\mathbf{2 0 1 4}$ & $3,426,000$ & 15 & 322 \\
\hline
\end{tabular}

Source: CIA Factbook, 2015; UNAIDS, 2016; World Bank, 2016.

Obviously, the MDG 6 was saddled with the responsibility of addressing the ugly cases of HIVIAids, malaria, tuberculosis and other diseases. No doubt, Nigeria has been grappling with the aforementioned health-related challenges which have posed serious threat to its corporate existence. Despite governmental policies deployed in meeting the goal six, the data as illustrated in the above table have shown that Nigeria performed poorly in the targets encapsulated in the MDG framework. For instance, the HIVIAIDS prevalence rate in Nigeria is high as the number of people infected with the deadly virus increased from 2.7 million in 2001 to 3.4 million in 2014. Similarly, the tuberculosis incidence in Nigeria is very alarming as the country has witnessed steady progression in the prevalence of the deadly disease. The occurrence rate stood at 331 in 2001, 343 in 2006 and 338 in 2013 as against 128 per 100,000 in 1990.

\subsection{Level of Women Empowerment in Nigeria}

Table 6: National Enrolment in Public Primary and Junior Secondary Schools, 2000-2012

\begin{tabular}{|ccccc|}
\hline & \multicolumn{2}{c}{ Primary School } & \multicolumn{2}{c|}{ Junior Secondary School } \\
\hline & Male & Female & Male & Female \\
\hline $\mathbf{2 0 0 0}$ & $10,738,025$ & $8,413,413$ & $1,264,903$ & $1,012,388$ \\
\hline $\mathbf{2 0 0 1}$ & $10,583,411$ & $8,457,812$ & $1,431,633$ & $1,148,535$ \\
\hline $\mathbf{2 0 0 2}$ & $11,070,610$ & $8,791,071$ & $1,746,909$ & $1,203,823$ \\
\hline $\mathbf{2 0 0 3}$ & $14,434,764$ & $11,338,280$ & $2,083,699$ & $1,600,945$ \\
\hline $\mathbf{2 0 0 4}$ & $11,824,494$ & $9,571,016$ & $1,972,637$ & $1,535,291$ \\
\hline $\mathbf{2 0 0 5}$ & $12,189,073$ & $9,926,369$ & $1,984,387$ & $1,639,776$ \\
\hline $\mathbf{2 0 0 6}$ & $12,492,091$ & $10,369,793$ & $1,653,753$ & $1,281,219$ \\
\hline $\mathbf{2 0 0 7}$ & $11,683,503$ & $9,948,567$ & $1,944,843$ & $1,531,220$ \\
\hline $\mathbf{2 0 0 8}$ & $10,768,742$ & $9,223,567$ & $2,150,037$ & $1,784,024$ \\
\hline $\mathbf{2 0 0 9}$ & $10,791,896$ & $9,288,980$ & $2,413,235$ & $2,022,016$ \\
\hline $\mathbf{2 0 1 0}$ & $11,027,686$ & $9,636,119$ & $2,703,938$ & $2,306,289$ \\
\hline
\end{tabular}




\begin{tabular}{|lllll|}
\hline $\mathbf{2 0 1 1}$ & $11,705,330$ & $10,420,087$ & $2,410,817$ & $1,902,347$ \\
\hline $\mathbf{2 0 1 2}$ & $12,571,483$ & $10,905,456$ & $2,408,578$ & $2,061,459$ \\
\hline
\end{tabular}

Source: Federal Ministry of Education, 2015.

Table 7: Percentage of Women in Nigeria's National Parliament, 2000-2015

\begin{tabular}{|c|c|}
\hline Year & Percentage of National Female Parliamentarians (\%) \\
\hline 2000 & 3 \\
\hline 2001 & 3 \\
\hline 2002 & 3 \\
\hline 2003 & 3 \\
\hline 2004 & 6 \\
\hline 2005 & 6 \\
\hline 2006 & 7 \\
\hline 2007 & 7 \\
\hline 2008 & 7 \\
\hline 2009 & 7 \\
\hline 2010 & 7 \\
\hline 2011 & 7 \\
\hline 2012 & 7 \\
\hline 2013 & 7 \\
\hline 2014 & 7 \\
\hline 2015 & 6 \\
\hline
\end{tabular}

Source: United Nations. Retrieved from http://mdgs.un.org/unsd/mdg/Data.aspx on 29/01/2015

The tables above represent the level of women empowerment in line with the Millennium Development Goal 3, which has the onerous task of promoting gender equality and empowering women. In table, Nigeria made little progress in its quest to achieve gender parity as there was improvement in the ratio of girls to boys enrolment in basic education (i.e. primary and junior secondary schools). As can be observed, there was steady growth 2000, 2001 to 2003. However, there was depreciation in 2004, 2008, 2009, and 2011.

Conversely, as regards to the proportion of seats held by women in the National Parliament as demonstrated in the table, Nigeria failed to meet up with the 35\% target anticipated in the MDG framework. With the figures in the tables above, we can generally conclude that Nigeria did not meet up with the Millennium Development Goal 3.

Table 8: Environmental Sustainability in Nigeria

\begin{tabular}{cccc}
\hline Year & $\begin{array}{c}\text { \% of Population with Access to } \\
\text { Improved Water }\end{array}$ & $\begin{array}{c}\text { \% of Population with Access to Improved } \\
\text { Sanitation Facilities }\end{array}$ & $\begin{array}{c}\text { \% of Land covered } \\
\text { by Forest }\end{array}$ \\
\hline $\mathbf{2 0 0 0}$ & 52 & 34 & 14.4 \\
$\mathbf{2 0 0 1}$ & 53 & 34 & 14.0 \\
$\mathbf{2 0 0 2}$ & 54 & 33 & 13.5 \\
$\mathbf{2 0 0 3}$ & 55 & 33 & 13.1 \\
$\mathbf{2 0 0 4}$ & 57 & 33 & 12.6 \\
$\mathbf{2 0 0 5}$ & 58 & 32 & 12.2 \\
$\mathbf{2 0 0 6}$ & 59 & 32 & 11.7 \\
$\mathbf{2 0 0 7}$ & 60 & 32 & 11.3 \\
$\mathbf{2 0 0 8}$ & 61 & 31 & 10.8 \\
$\mathbf{2 0 0 9}$ & 62 & 32 & 10.4 \\
$\mathbf{2 0 1 0}$ & 63 & 32 & 9.9 \\
$\mathbf{2 0 1 1}$ & 65 & 30 & 9.5 \\
$\mathbf{2 0 1 2}$ & 66 & 30 & 9.0 \\
$\mathbf{2 0 1 3}$ & 67 & 30 & 8.6 \\
$\mathbf{2 0 1 4}$ & 68 & 29 & $\mathrm{~N} / \mathrm{A}$ \\
$\mathbf{2 0 1 5}$ & 69 & 29 & N/A \\
\hline
\end{tabular}

Source: World Bank. Retrieved from http://data.worldbank.org/indicator, on 29/01/2016. 
The data reflected in the above table represents the outcome of various indicators of Millennium Development Goals 7 . As captured in the Millennium Development framework, the goal 7 has the task of ensure environmental sustainability in Nigeria. In terms of access to improved water, Nigeria made steady and significant progress as the percentage increased from $52 \%$ in 2000 to an end-point status in 2015 at $69 \%$ access. Meanwhile, this feat could not be replicated with respect to the proportion of the population using improved sanitation facilities as the figure witnessed consistent decline from 34\% in 2000 to $29 \%$ in 2015 . Also, the percentage of land covered by the forest as witnessed continuous depreciation from $14.4 \%$ in 2000 to $8.6 \%$ in 2013.

On the other hand, available statistical information have shown that Nigeria met the Millennium Development Goal 8 which was premised on developing global partnership for sustainable development. According to an end-point report from the Office of the Senior Special Assistant to the President on Millennium Development Goals:

Nigeria has performed better on this goal as compared to the others. There has been a rising trend in per capita Official Development Assistance (ODA) with potential impact felt in infrastructure and human development. The appreciable decline in debt service as a percentage of exports of goods and services is attributed to the debt relief granted in 2005. The socio-economic benefits associated with Information and Communication Technology (ICT) has seen to appreciable growth in the industry. The growth in the number of cellular phone subscribers and the tele-density per 100 people standing at 77.8 and 99.3, respectively, in 2014 signifies wide coverage. Conversely, the growth in the number of internet users per 100 people, standing at 42.68 in 2014 implies that there is need to step up interventions in this sector (OSSAP-MDG, 2015:9).

Deriving from the above information, it will be objective to conclude that Nigeria met the Millennium Development Goal 8.

Nevertheless, with the failure of Nigerian state to achieve most of the Millennium Development Goals, scholars and policy makers have been preoccupied with the task of interrogating the causations. As a result, many studies have made attempt to unravel the factors that impeded on the realization of the MDGs in Nigeria. Challenges such as corruption, inaccessibility of the means of production by the poor, global recession of 2008/2009, lack of human capacity and implementation, inadequate and unreliable statistical data, policy inconsistencies, weak institution, poor coordination between different tiers and arms of government and high rate of poverty were identified as factors that militated against the achievements of Millennium Development Goals in Nigeria (ljaiya, Bello, Adeyemi \& ljaiya, 2008; Abgdulgafar, Ibrahim \& Alasinrin, 2013; Ajiye, 2014; MDG-Nigeria, 2015).

However, while the study does not out-rightly ignore or discard the aforementioned scholarly positions, we however, believe that the views adduced above may not be sufficient reasons for the failure of the MDG objectives in Nigeria. Radically departing from the conventional or existing knowledge, we observed that beyond the above outlined impediments to the realization of the developmental policy frameworks as argued by scholars, the actual missing-link in achieving the MDG policy frameworks and other developmental strategies in Nigeria appears to be non-adherence to the basic dictates of politics by the policy-makers. This is because; the rate at which the missions and visions of MDG will be actualized solely depends on the understanding of the ideal meaning and dynamics of politics. As a corollary of the above, the next section will attempt to establish the synergy cum relevance of Political Science to the actualization of the Sustainable Development Goals in Nigeria.

\section{Political Science and Achievement of Sustainable Development Goals (SDGs) in Nigeria}

Undoubtedly, the term "Politics or Political Science" appears to be the most controversial and misunderstood concept in the world especially among politicians and political jobbers in the third world countries. The concept has acquired different usages, meanings, connotations and explanations by the layman, analyst and even the practitioners. In an unsavoury, pejorative and most distorted sense, there has been a tendency to link the most revered concept of politics and political science to duplicity, guile, cheating, manipulation, maneuvering for advantage, scheming, cunning and craftiness. To others, the venerated concept is seen as a game and is often described as dirty. This underscores why politicians often refer to their various dubious activities as politics and that informed why the political leaders acquire power to indulge in fraudulent and unethical activities.

Arising from above, there has been difficulty in assigning a universal meaning to the term politics or political science as scholars disagreed on a unified binocular in viewing or explaining the concept. For instance, Ranney (1966) defined politics as the governing of men, Easton (1965) see it as the authoritative allocation of value, Lasswell (1939) see politics as who gets what, when and how. Nnoli (1981), however, defined the politics as all the activities that directly or indirectly led to the acquisition or seizure of state power, use of state power and consolidation of state power. While we 
cannot completely ignore the views of other scholars like Nnoli (1981), their perceptions failed to capture the basic ingredients for proper understanding of politics. For us, our explanation of politics and political science and its relevance in achieving the Sustainable Development Goals in Nigeria will be anchored on the evolutionary and functional perspective as it intends to bring out the underlying principle of the concept.

The rationale for politics can be intuitively drawn from the state of nature as propounded and hypothesized by Hobbes (1651). Hobbes (1651) in his philosophical analysis viewed man as an isolated, egoistic, and self interested, and seeking society as a means to their end. Individuals were creatures of desire, seeking pleasure and avoiding pains. In the light of this bleak and pessimistic human nature, the picturization of the state of nature was gloomy and sordid. To this end, Hobbes maintained that;

In such condition, there is no place for industry, because the fruit thereof is uncertain, and consequently no culture of the earth; no Navigation, nor use of commodities that may be imported by the sea; no commodious building, no instrument of moving such things as require much force, no knowledge of the face of the earth; no account of time, no arts, no letters, no society; and worst of all, continual fear, and danger of violent death. And the life of man, solitary, poor, nasty, brutish and short (Hobbes, 1651 cited in Mukherjee \& Ramaswamy, 2007:175).

Hobbes saw man's relationships as those of mutual suspicion and hostility. The only rule that the individuals acknowledged was that rule one would take if one has the power, and retain as long as one could. In this state of nature, there was no law, no justice, no notion of rights and wrongs, no institutional mechanisms of the state, with only force, fraud and anarchy as the cardinal virtues. The principal causes of conflict according to Hobbes were competition, diffidence and glory. Elucidating further, he opined that;

The first (competition) maketh men invade for gain, the second (diffidence) for safety and the third (glory) for reputation. The first uses violence to make themselves masters of other men, the second to defend, and the third for trifles (Hobbes, 1651 cited in Mukherjee \& Ramaswamy, 2007:175).

Hobbes did not attribute the predicament of the natural person to either sin or depravity but to human nature. The individual was the author of his own ruination. The state of nature degenerated into a state of war "a war of every man against every man". Due to the unlimited and unrestricted capacity of human rights and liberty, the life of man in the state of nature was short, nasty, brutish, poor and solitary (Mukherjee \& Ramaswamy, 2007).

Owing to the hostility and anarchy that almost threatened the social existence of man in the state of nature, it dawns on them that there is need to come together and proffer a possible solution out of their predicament and agony that opposed their development and survival. To this end, they assembled and entered into historic covenant where, individuals agreed to surrender all their powers and rights of governing themselves through a contract to a constituted authority who was not a party to the contract, but nevertheless received all the powers that were surrendered. As captured succinctly by Thomas Hobbes during the agreement, the multitude said to the other:

I authorize and give up my rights of governing myself, to this man, or to the assembly of men, on this condition that thou give up thy right to him, and authorize all his actions in like manner (Hobbes 1651 cited in Mukherjee \& Ramaswamy, 1999).

By surrendering his rights and consenting to a set of rules, every individual is guaranteed basic equality with every other member. This means that no man had more power than the other. The contract created civil society and political authority, for it was a social and political contract. The contract equally created the state and government simultaneously which is undivided, unlimited, inalienable and permanent.

Furthermore, in the course of the social contract, each party to the agreement was assigned specific roles i.e. individual roles and government roles. While the individuals will submit their unlimited rights to the state, adhere strictly to the set of rules and regulation guiding the co-existence of fellow men, be loyal to the constituted authority and pay their tax, the government roles includes responding to the needs of the people, protecting the individuals rights, ensuring fairness, equity and justice among men, securing their lives and properties etc. There is also penalty agreed upon by each party that does not conform to the provision of the social contract. While the state will employ its coercive apparatus (police, standing army and law courts) to compel and secure compliance from dissident citizens, the people are also compelled through the instrumentality of civil society to react and resist against unjust laws, unfair treatments, inability to meet their need, arbitrary use of power by the state. The people can register their grievances through dialogue, protest, riot and sometimes, rebellion.

From the foregoing analysis, it is quite clear that social contract is the foundation and basis for politics. Social 
contract forms the basis for politics, quality leadership and followership, good governance, politics is the means of reaching the goals of social contracts. In the same vein, social contract entails corporate responsibility and responsiveness by both parties to the agreement while politics is the framework for authoritative allocation of value designed for the realization of human destiny (goals of social contracts). Both are closely related and inextricably interwoven.

Politics and indeed, political science is a veritable tool for building an ideal and modern society. It is also a knowledge-based approach saddled with the responsibility of effecting fundamental changes necessary for the attainment of the good society. Similarly, the relevance was equally reinforced by Asobie (2008) when he noted that political science is the architectonic science: that which shapes the environment within which other sciences are pursued. As an architectonic science, it determines the workings, functioning and continued existence of the society. Hence, the implication of the foregoing analysis is that political science or politics remains the means through which human race can achieve equilibrium in any environment they find themselves.

Politics is a rational and complex activity in the sense that it is peculiar to human beings. Among animals, man is the only being that can indulge in political activities; hence, politics starts and ends with man. It's all about meeting the needs of the people and by extension impacting positively and maximally on their welfare.

To us, politics is the legitimate acquisition of state power to create value, equitable distribution of value and sustenance of value for the purpose of maximizing human welfare. This notion is a radical departure from the popular view held by analysts and practitioners of politics. The popular notion about politics centers its analysis on the distribution of value without recourse on how those values are created and how to sustain it for futuristic purpose and unforeseen contingencies. For a perfect understanding of politics, let's elaborate on the underlying characteristics culled from our definition:

- Politics is centered on state and legitimate acquisition of state power: following the Aristotelian analogy that man by nature is a political animal, there is a tendency to reduce the concept of politics to merely human interaction. However, owing to the social contract, the state became the basis of politics. Under the extant International Laws, the state is empowered to make laws for social order, progress, stability, and wellbeing of citizens. It is also authorized to authoritatively determine how scarce values will be evenly allocated. Hence, the first step of politics is to seek for state power and emphasis should be placed on seeking it legitimately in accordance with the civilized conventions.

- Creation of values: the second element in understanding the concept of politics has to do with the creation of value. Conventionally, no organization, business and society can survive without a viable and continuous means of material existence. It is also imperative to state that naturally, production starts with the exploitation of natural resources that will be used in the creation of goods and services for the satisfaction of human wants. Every state is endowed with abundant human and natural resources that will be instrumental in the production of material means of existence. Creation of value entails harnessing the material and human resources that abounds in a particular location by the government and developing them in the process for the satisfaction of human wants. Creation of value starts by identifying and developing human beings who are the catalyst for development. It's quite obvious that the natural endowment of a state will continue to be in its crude form until human knowledge is applied. In this sense, development of human beings includes acquisition of the necessary skills and knowledge through qualitative education for the task of interacting and humanizing nature. Moreover, harnessing resource is all about carrying out a holistic feasibility study to ascertain the enormous gift of nature that will be used in satisfying human wants. All the natural endowments are deposited for the satisfaction of human wants.

In Nigeria, this has been the bane of development; the Nigerian leader lacks the political temerity to optimally harness and utilize the available natural endowment to satisfy human wants. This ugly incidence can be attributed to the popular and unprogressive orientation held by the leaders on politics as nothing but the authoritative allocation of value. Conventionally, following the logical way of doing things, one has to create means of livelihood before sharing with people. In the same way, it is the responsibility of the state to create means of providing means of livelihood for its citizens.

- Equitable distribution of value: Another important task of politics is the equitable distribution of value. After creating the means of livelihood, it's the responsibility of the state to authoritatively allocate these values equitably. Here values include the basic amenities, adequate security, functional and equipped health facilities, sound and qualitative educational system, befitting job opportunities etc. In the process of allocating values equitably, government should strive towards creating the necessary environment that will propel development. Emphasis is placed on the equity because; government belongs to all people irrespective of 
religious and tribal differences. However, there is a major departure of this notion as political leadership is seen as a means to authoritatively allocate or compensate friends, tribal and religious members. Political and bureaucratic appointments are based on religious and tribal affiliation instead of merit. Mediocrity is widely celebrated as an institutionalized norm in public service while meritocracy is relegated to the background.

- Sustenance of value: Politics does not only concern itself with the responsibility of creating and distributing resources or value, considers the survival of the people in the future. The political leadership concerns itself on how to continue providing for the people in the future. It entails continuous improvement and investing the resources in its quest to protect the future of the people.

- Maximization of human welfare: Politics centers on human beings and by extension his/her welfare. This is the hallmark of politics. The state has the onerous task of maximizing the welfare of the people by creating the necessary environment that will help them to achieve their dreams and aspirations in life and reproduce the ingenuity in them. Human welfare maximization entails the provision of good medical facilities, access to good job opportunities, access to standard and sound educational system, efficient and effective transportation and communication system, reliable security, constant power supply etc. In contrast to this notion, Nigerian leadership has completely left their statutory responsibilities of maximizing human welfare. The sorry state of human development index is appalling as the poverty and unemployment rate is high.

Arising from the above elaboration, it is clear that politics is, fundamentally, about material and human development; and development begins with production, and not with distribution or sharing. On the contrary, the aforementioned features of politics were non-existent in Nigeria and that, has accounted for the failure of virtually all developmental strategies evolved to salvage the Nigerian challenges including the Millennium Development Goals initiatives.

\section{Conclusion}

Undeniably, the Millennium Development Goals remains a genuine commitment by World Leaders to rid the international system of the fundamental challenges that beset the developing countries. Like other developing countries, Nigeria keyed into the imitative as a means of reconciling the development deficit inherent in her polity. However, from all indicators shown in the tables, Nigeria's performance within the framework of MDG was abysmally below expectation as the country failed to meet up with seven out of the eight goals. The study beyond the conventional views of scholars implicated nonadherence of the tenets of politics as the major factor that impeded on the achievement of the Millennium Development Goals. As the journey for the Sustainable Development Goals begin in 2016, we outlined and elaborated on the viable means and conditionalities for achieving the development agenda in Nigeria.

In view of the foregoing, we make the following recommendations:

- That the political class should as a matter of priority incorporate the basic principles of politics as means of reaching their development objectives.

- That Nigeria leadership must begin to afford political scientists the opportunity to participate in formulation and implementation of development-oriented policies.

\section{Acknowledgements}

Group research by staff and students of the Department of Political Science, University of Nigeria, Nsukka, Nigeria.

\section{References}

Agbaeze, E.K., Udeh, S.N. \& Onwuka, I.O. (2015). Resolving Nigeria's dependency on oil-The derivation model. Journal of African Studies and Development, Vol. 7. No. 1.

Abdulgafar, D. S., Ibrahim, W., Alasinrin, K.A. (2013). The extent of achieving the Millennium Development Goals: Evidence from Nigeria. Kuwait Chapter of Arabian Journal of Business and Management Review, Vol. 2, No.9; May.

Ajiye, S. (2014). Achievements of millennium development goals in Nigeria: A critical examination. International Affairs and Global Strategy Vol.25, 2014 www.iiste.org

Ake C. (1981). Political economy of Africa. Lagos. Longman Publishers.

Ake, C. (1985). The State in Contemporary Africa' in C. Ake (ed.), A political economy of Africa. Lagos: Longman.

Ake, C. (1996). Democracy and development in Africa. Ibadan: Spectrum Books Limited.

Alavi, H. (1972). The state in post-colonial societies: Pakistan and Bangladesh. New Left Review, 7 (2).

Annan, K. (2000). We the peoples: The role of the United Nations in the Twenty First Century. New York: United Nations. 
Asobie, H. A. (2007). Reinventing the study of international relations from state and state power to man and social forces. Being an Inaugural Lecture Presented at University of Nigeria, Nsukka on $18^{\text {th }}$ July.

Bradford, C. (2006). History of the MDGs: A personal reflection. Mimeo. Washington DC: Brookings Institution.

Bromley, D.W. (1995). Development reconsidered: The African challenge. Food Policy 20(5):425-438.

Hobbes, T. (1651). The leviathan. University of Michigan Press. Michigan.

Callaghy, T. (1986). The political economy of African debt: The case of Zaire. In Ravenhill, J. (ed.) Africa in economic crisis. London/New York: Macmillan/Columbia University Press.

Carmody, P. (1998). Constructing alternatives to structural adjustment in Africa. Review of African Political Economy 25 (75): $25-46$.

CBN (2010). Central Bank of Nigeria statistical bulletin. Vol. 21. CBN Press, Abuja.

CBN (2015). Central Bank of Nigeria annual report and statement of accounts, CBN, Abuja.

Christiaensen, L.J., Demery, L. \& Paternostro, S. (2001). Growth, distribution and poverty in Africa: Messages from the 1990s. Washington, D.C.: The World Bank.

Central Intelligence Agency (2015). The CIA world fact book. Washington DC: Skyhorse Publishing Inc.

Cornia, G. A., Richard, J. \& Stewart, F. (1987), Adjustment with a Human Face: Protecting the Vulnerable and Promoting Growth. Oxford. Clarendon Press.

Cornia, G.A. \& Helleiner, G.K. (1994). From adjustment to development in Africa: Conflict, controversy, convergence, consensus? MacMillan, London.

Dawodu, S.T. (2015). Politics and crisis in Nigeria. Retrieved from www.dawodu.com/crisis1.htm, on 29th December, 2015.

Deneulin, S. and Shahani, L., (2009). An introduction to the human development and capability approach: Freedom and agency. London: Earthscan.

Dike, V. (2010). Corruption in Nigeria: A new paradigm for effective control. Africa economic analysis. Available at www.Africa EconomicAnalysis.org.

Dike, V.E. (2010). Review of the challenges facing the Nigerian economy: is national development possible without technological capability? Journal of Sustainable Development in Africa, Vol. 12, No.5.

Easterly, W. (2000). The effect of IMF and World Bank programs on poverty. Mimeographed. Washington, D.C: The World Bank.

Easton, D. (1965). A framework for political analysis. Englewood Cliffs: Prentice-Hall Inc.

Ejumudo, K.B. (2013). The problematic of development planning in Nigeria: A critical discourse. The International Institute for Science, Technology and Education Journal (IISTE), Vol.3, No.4.

Ekekwe, E. (1986). Class and state in Nigeria. Lagos: Macmillan Publishers.

Engels, F. (1884). Origin of family, private property and the state. Zurich: Hottingen Press.

Eme, O. \& Okwueze, F. (2014). National Assembly and its controversial pension: A critique. Singaporean Journal of Business Economics and Management Studies, Vol. 3, No. 1.

Federal Ministry of Education (2015). Annual report of the Nigeria Federal Ministry of Education. FME: Abuja.

George, I.N. \& Ukpong, D.E. (2013). Contemporary social problems in Nigeria and its impact on national development: implication for guidance and counseling services. Journal of Educational and Social Research, Vol. 3(2).

Ibeanu, O. (1998). The Nigerian state and the politics of democratization. A paper presented at a conference for the book project on comparative democratization in Africa: Nigeria and South Africa, University of Cape Town, South Africa, 31st May-1st June.

Ijaiya, G.T., Bello, R. A., Adeyemi, S.L. \& ljaiya (2008). The Millennium Development Goals and socio-economic indicators in Nigeria. Indian Journal of Development \& Social Action, Vol. 4 (1-2). Pg. 29-37.

Ilugbuhi, T. O. (1968). Nigeria's experience in domestic financing of development. Institute of Administration, Research Memo Series, Zaria, Nigeria.

International Monetary Fund (2014). Nigeria: Selected issues and statistical appendix. Washington DC. IMF Press.

Lasswell, H.D. (1936). Politics; Who gets what, when and how. New York: Whittlesey House.

Lenin, V.I. (1918). The State and revolution. Moscow: Free Press.

Marguerite, P. A. (2010). MDGs-UN conference process: Ideological continuum. Retrieved from www.dialoguedynamics.com.contenu/ learning-forum/seminars/the-millennium-development-goals/the-millennium-development-goals.htm, on 2 ${ }^{\text {nd }}$ January, 2016.

Marx, K. \& Engels, F. (1848). The Communist manifesto. Moscow: Free Press.

Mukherjee, S. \& Ramaswamy, S. (2007). A history of political thought: Plato to Marx. New Delhi. Prentice-Hall of India Private Ltd.

National Bureau of Statistics (2011). 2011 annual socio-economic report, Abuja: National Bureau of Statistics.

National Bureau of Statistics (2012b). Millennium Development Goals survey 2012. Abuja: NBS.

National Planning Commission (2010). Count strategy to 2010-2015; Achieving MDGs. Abuja. National Planning Commission.

National Planning Commission (2010). Millennium Development Goals report 2010. Abuja: National Planning Commission.

Niger Delta Politics (2012). A very brief chronology of oil economy. Retrieved from https://nigerdeltapolitics.wordpress.com/tag/oilproduction/, on $16^{\text {th }}$ January, 2016.

Nnoli, O. (1981). Path to Nigerian development. Dakar. CODESRIA.

Nnoli, O., (1986). Introduction to Politics. Lagos: Longman.

Nnamani, E.K. (2015). International Monetary Fund and crisis of development in Nigeria, 2000-2014. Unpublished M.Sc Thesis submitted for the Award of Master of Science Degree in Political Science, University of Nigeria, Nsukka.

NYSC/British Council/World Bank/Institute for Community Development Project (2007). Debate to action: Development in my community. Lagos: Prince of Prints Limited. 
Obasanjo, O. (1999). Inaugural speech by His Excellency, President Olusegun Obasanjo following his swearing-in as President of the Federal Republic of Nigeria on May 29, 1999. Retrieved from www.nigeriaworld.com/feature/speech/inaugural.html, on 29th December 2015.

Odubiyi, A. (2013). The history of the Nigerian petroleum industry. http://www.oilandgasforum.com.ng/oil-gas-51/the-history-of-thenigerian-petroleum-industryl.

Okolie, A.M. (2015). Global political economy and development of underdevelopment: Different people, same market and glorification of poverty. Being an Inaugural Lecture Presented at University of Nigeria, Nsukka.

Olowu, D., Laleye, M. \& Ayeni, V. (1982). The Nigerian economy and economic policy responses. Retrieved on $16^{\text {th }}$ January 2016, from: www.unpan1.un.org/intradoc/groups/public/documents/.../UNPAN026544.pdf

Olubunmi, L., Ayantoye, K. Agboola, T.O. \& Akinwole, T.O. (2015). Leadership and governance: dilemma of agricultural development in Nigeria. International Journal of Politics and Good Governance Volume VI, No. 6.4 Quarter IV.

Onimode, B. (1983). Imperialism and underdevelopment in Nigeria: the dialectics of mass poverty. London. Macmillan Press.

Onuoha, F.C., Ichite, M. \& George, T.A. (2015). Political, economic and security challenges facing President Buhari. Al-Jazeera Centre for Studies.

Organization of African Unity (1980). Lagos plan of action for the economic development of Africa, 1980-2000. OAU Press. Addis Ababa.

OSSAP-MDGs (2008) Mid-point assessment of the MDGs in Nigeria. Abuja. OSSAP-MDGs

OSSAP-MDGS (2010).MDGs count-down strategy. Abuja. OSSAP-MDGs

OSSAP-MDG (2015). Nigeria 2015 millennium development goals end-point report. Abuja. OSSAP-MDG.

Osman, A. (1994). Mugging the poor: the Bretton Wood Institutions and the pursuit of African development. Being an IFAA contribution to the $50^{\text {th }}$ anniversary of the Bretton Woods Institutions. International for African Alternatives (IFFA). London.

Ranney, A. (1966). The governing of men. Rinehart and Winston. Holt.

Saheed, Z. \& Egwaikhide, C.I. (2012). Impact of social crises on economic development: Theoretical evidence from Nigeria. American International Journal of Contemporary Research Vol. 2 No. 6; June 2012.

Saul, J.S. (1974). The State in Post-Colonial Societies: Tanzania. The Socialist Register, Toronto Canada.

United Nations (2001). Road map towards the implementation of the United Nations millennium declaration: Report of the SecretaryGeneral, document A/56/326. New York: United Nations.

United Nations (2015). The millennium development goals report of 2015. New York. UN Publishers.

United Nations Development Programme (2009). Human development report Nigeria. 2008-2009: Achieving growth with equity. Abuja: UNDP.

United Nations Development Programme (2014). Human development report 2014. Sustaining human progress: Reducing vulnerabilities and building resilience. New York. UNDP

UNDP (2015). Human development index. Retrieved from https://hdr.undp.org/en/content/human-development-index-hdi, on $27^{\text {th }}$ November, 2015.

UNAIDS (2016). HIV/AIDS estimates in Nigeria. Retrieved from www.unaids.org/en/regionscountries/countries/nigeria.

World Bank (2013). Nigeria economic report No. 1. Abuja: World Bank

World Bank. (2014). World development indicators database. Washington, DC. http://data.worldbankorg/data-catalog/worlddevelopment-indicators. Accessed on 11 November, 2015.

World Bank (2015). Nigeria economic report of 2015. Retrieved from https://www.wordbank.org/en/country/nigeria, on $25^{\text {th }}$ November, 2015.

World Bank. (2016). World development indicators database. Washington, DC. http://data.worldbankorg/data-catalog/worlddevelopment-indicators. Accessed on 13th January, 2016. 